\title{
TTR
}

Traduction, terminologie, re?daction

\section{Keeping One's Distance: Translation and the Play of Possibility}

\section{Michael Cronin}

Volume 8, numéro 2, 2e semestre 1995

Technolectes et dictionnaires

URI : https://id.erudit.org/iderudit/037225ar

DOI : https://doi.org/10.7202/037225ar

Aller au sommaire du numéro

\section{Éditeur(s)}

Association canadienne de traductologie

ISSN

0835-8443 (imprimé)

1708-2188 (numérique)

Découvrir la revue

Citer cet article

Cronin, M. (1995). Keeping One's Distance: Translation and the Play of Possibility. TTR, 8(2), 227-243. https://doi.org/10.7202/037225ar

\section{Résumé de l'article}

En gardant ses distances: Ia traduction et le jeu du possible - Cet article propose une théorisation ludique de la traduction examinant les implications du concept de jeu pour la théorie et la pédagogie de la traduction. L'équation du jeu avec un mode simulatif d'action fait ressortir le caractère central des mécanismes d'identification et de projection dans la classe de traduction-interprétation. Le passage du niveau pré-opérationnel au niveau opérationnel de logique et le passage des dimensions métacommunicative et métalinguistique au jeu et à la traduction démontrent l'importance cognitive de ces activités dans le développement intellectuel et la constitution de l'identité. Le jeu, la métaphore et la traduction sont liés dans le concept de la pensée bisociative qui fonde la créativité essentielle de la traduction et sa capacité de découverte. La nature paradoxale de la traduction et du jeu est envisagée tant en relation avec les possibilités cognitives de la traduction que sous l'angle de sa contribution à un renouvellement esthétique. L'utilisation d'une division tripartite de types ludiques de textes dans la formation des traducteurs et le potentiel créatif des limites sont une preuve de plus en faveur de l'importance de la dimension ludique de la traduction.
Tous droits réservés @ C TTR: traduction, terminologie, rédaction — Les auteurs, 1995 document est protégé par la loi sur le droit d'auteur. L’utilisation des services d'Érudit (y compris la reproduction) est assujettie à sa politique d'utilisation que vous pouvez consulter en ligne. 


\section{Keeping one's distance: Translation and the play of possibility}

\section{Michael Cronin}

The concept of play in translation theory has long remained on the margins. When it appears, it is generally as part of post-structuralist or Derridean readings of language and translation. The ludicity of translation is not, however, the chance product of cultural fashion and does in fact highlight at a fundamental level aspects of translation that are central to its value for human thought and creativity. In addition, translation pedagogy can usefully learn from an approach to translation that eschews doctrinaire instrumentalism for the ludic possibilities of open-endedness. In this article, the concepts guiding this ludic theorisation of translation will be simulation, metaphor, paradox, distance and limits.

Everybody recognises play but few successfully define it. In order to clarify, however, what is meant by play, it is useful to examine a number of definitions that have been offered by theoreticians of play. Johan Huizinga (1949) in Homo Ludens defines play as a:

free activity standing quite consciously outside 'ordinary life' as being 'not serious', but at the same time absorbing the player intensely and utterly. It is an activity connected with no material interest and no profit can be gained by it. It proceeds within its own proper boundaries of time and space according to fixed rules and in an orderly manner. It promotes the formation of social groupings which tend to surround themselves with secrecy and to stress their difference from the common world by disguise or other means (p. 13). 
Roger Caillois, the French poet and critic, in Les jeux et les hommes (1967) defined le jeu as an activity that was free, separate, uncertain, unproductive, governed by rules and involving make-believe (pp. 4243). Michel Picard in his La lecture comme jeu (1986) is more attentive to the psychoanalytical dimension of play as is evident in the definition he offers:

Quant à ses fonctions, le jeu, en relation manifeste avec la symbolisation serait á la fois défensif et constructif; procurant une maîtriseparticulière (s'irréaliser pour se réaliser') il remplirait un rôle intégrateur capital, tant interne qu'externe (donc aux deux sens du mot). Quant à ses formes, il s'agirait d'une activité, absorbante, incertaine, ayant des rapports avec le fantasmatique, mais également avec le réel, vécue donc comme fictive mais soumise à des règles (p. 30).

Elements that emerge as common denominators in the definitions are the notions of integration, initiation, the existence of rules and distance from everyday life. Both Huizinga and Caillois emphasise the fictive quality of games, a point developed further by Peter Reynolds in his essay "Play, Language and Human Evolution" (1976). Reynolds equates play with a simulative mode of action, where the actions of play do not have the same consequences that they would have in other systems, "the simulative mode of action is paradoxical: the system's [i.e. of the group at play] operations should have their normal consequences, yet those consequences must at the same time be rendered inconsequential" ( $p$. 621). Thus, in addition to being paradoxical (a crucial point to which we shall return), play allows the players to imitate, through actions, aspects of the real, "the survival-oriented activity of the species" without having to assume the routine effects of such actions. This, in turn, partly explains the association for many of play with childhood, "the young individual, not being required to respond 'appropriately' to most actions of adults, is free to imitate them" (p. 625).

\section{Simulation, logic and teaching}

In many games of make-believe what goes unnoticed in real life such as the relationships between parents, siblings or the activities of different professional groups becomes a rule of behaviour in play, structuring the imaginary situation of the game (Vygotsky, 1976, p. 
542). In the transition from the visible to the cognitive realm, the meanings of actions and objects take precedence over the actual objects and actions in the simulative world of the game. It precisely this simulative world which prepares us for the imaginary world of reading, made possible by liberating meanings from concrete phenomena, allowing language to emerge and accustoming us to the simulative mode of existence, for example, in fiction.

The simulative mode underpins translation theory. What goes unnoticed in translation practice ('real life') becomes a rule or observation in translation theory ('play'). The hostility of practitioners to translation theory and theoreticians is partly based on theory's exposure of the rule-based or the presupposition-driven nature of translation. Theory destroys the 'naturalness' of the translation experience. In this respect, it is similar to much-maligned literary theory that is frequently accused of vitiating the primary pleasure of the text through exhaustive critical analysis.

Reynolds sees play as central to human evolution and this point is elaborated further by Sutton Smith in her linking of play to the development of abstract thought. When children play, there is the shift from pre-operational, 'as is,' level of logic to the operational level of 'as if' (Stewart, 1978, pp. 36-37). Playing various roles allows the formulation of hypotheses, the positing of consequences or the development of corollaries. The anthropologist, Gregory Bateson, for his part, sees the playful nip that is not a bite as the crucial step forward in the development of communication systems in higher primates. By framing what would normally be a menacing, aggressive action as something playful, the basis is laid for the self-reflexive framing that underlies all metalinguistic and metacommunicative abilities (Bateson, 1978).

These observations by theoreticians of play point to the often neglected role of translation in individual intellectual development as opposed to general cultural enrichment. That is to say, translators work a great deal of the time in the 'as if,' hypothetical mode trying out various solutions, selecting one version, rejecting another and so on. They play with the translation possibilities of the text. The dual processes of identification and projection, at the heart of all ludic 
activity, are also basic to the art of translation. It is noticeable, for example, that in simultaneous interpreting classes, it is students who project themselves into the persona of the speaker and identify with the emotional and cognitive thrust of the speech that produce the most successful interpretation. The interpreter's projection and identification, of course, is playful. It only lasts the duration of the speech. S/he does not have to 'really' share the opinions or prejudices of the speaker. Similarly, the translation student who returns from a year abroad shows the greatest improvement in the areas of projection and identification i.e. $s$ /he finds it considerably easier to project themselves into the universe of discourse of the source language text, thus facilitating the identification of target audience, register and text type. On the other hand, in the target language, the most difficult task for translation students is, precisely, successful projection. Many students come straight to university after secondary school, and, therefore, have limited life experience. Thus, there are many text types that they will probably not have come across (for example in the area of patents, medical documentation) or registers which they will not be familiar with in their own language. A difficulty in interpreting EC speeches is that students will have had little or no previous occasion for formal speech-making in their own lives.

Translation, therefore, is constantly working at the operational level of logic. The various attempts at successful translations of words, phrases, passages, texts involve repeated, hypothetical framing of the items to be translated. This is not a bite (the final version) only a playful nip (a provisional translation, open to more revisions and changes). At a deeper level, one could argue that what translation effectively does is to assist the self in the elaboration of identity, the constant that emerges through the multiple metamorphoses of projection and identification. More pragmatically, translation is worthwhile not only because it promotes international understanding, foreign trade and the dissemination of ideas and literatures (translation as product) but because it develops the cognitive skills of hypothetical thinking, foresight and speculative abstraction (translation as process). A fuller appreciation of the profoundly ludic nature of translation activity has a number of consequences for the teaching of translation. 
1. It shows why teaching is necessary. Students must have the opportunity to operate in a simulative mode where wrong translation choices would not have the consequences they normally would have in an agency, software localisation firm or international organisation. However, it is worth pointing out if the simulative mode is divorced from the real in terms of outcome for the student translator, in terms of process, it exactly comparable to the mode of operation of the professional translator in real-life situations. Thus, while tired distinctions between the 'unreality' of translator training and the 'reality' of translation practice are often used as a means of evacuating theory, a simulative approach on the contrary shows that theory and practice are inseparable.

2. Students who cannot play will not learn. Excessively prescriptive or normative approaches to the teaching of translation which are teachercentred hamper the development of autonomous hypothetical and speculative abilities in the student. The translation teacher who uses his/her own fair copy, as Holy Writ is depriving students of learning opportunities in the translation area.

3. More thought must be given in translation pedagogy to the improvement of projection and identification skills. Previously, translators after doing all kinds of jobs and spending long periods of time abroad ended up, often by accident, in translation. The situation is now different with the development of university training courses in many countries where the student intake is largely post-secondary school. The challenge for translation teachers is to try and make up for the experience deficit in both target and source languages. By focusing on projection and identification in the translation process it should be possible to develop a ludic pedagogy that would increase not only translators' self-understanding but make them more mature and effective as translators.

\section{Distance}

James Joyce punning endlessly in Finnegans Wake demonstrates not only the creative arbitrariness of the signifier but also implicitly contests the more deterministic forms of linguistic relativism. Play with language demonstrates a human ability to stand outside normal uses and meanings 
of words and to paradoxically suggest others. Word play is, therefore, predicated on the metalinguistic ability of humans. Similarly, successful translation is based on the translator's ability to distance himself/herself from the source and target languages (particularly the former). Problems of linguistic contamination, lexical and syntactic faux-amis, gallicisms and anglicisms in the French-English/English-French pair are basically problems of distance, of the apprentice translator's inability to keep his/her distance from the language of the text to be translated.

Of course, distance can occur as a notion in many different guises in translation studies. There is distance as expressed through verbal aspect and the consequent translation difficulties arising out of temporal organisation of narrative in different languages (cf. de Jong et $a l ., 1993)$. Or there is the notion of distanciation as expressed in the structural hermeneutics of Ricoeur. In the transition from spoken to written discourse, a number of things happen to language and what a translator's poetics might consist of, Cees Koster argues, is finding the right strategy of recontextualisation, overcoming the distance implicit in the transition (cf. Koster, 1993). To the linguistic and hermeneutic notions of distance, one can add a third, the ludic. The translator operates, in effect, in that no-man's land between languages, the l'entredeux of translation possibility. This is not to say that the translator is a free-floating signifier, that $\mathrm{s} / \mathrm{he}$ is not the product of a culture, time and language. Translators are nevertheless different from monoglot writers in a language because they must remain at a remove from the SL text, or else they produce Frenglish, Spanglish or Janglish (Japanese-English). This verfremdung is integral to the translator's art. It underlies the ludic dialectic of translation, the escape from one language which becomes an initiation into the other.

A related observation is the consistently low status of translators in societies. It may be, indeed, that translators like the cosmopolitan writers of modernity are treated as somewhat suspect. They work in but are not fully of the language. They maintain this contact with the other. They always keep a critical distance from the languages they work with and, by extension, are not wholly and uncritically at one with any language or culture. A staple of anti-semitic discourse is the notion of the Jew as Wanderer, Cosmopolitan, Rootless. The translator, too, can be caricatured as all these things. Hence, the 
slowness and reluctance to acknowledge the important role of translators in culture and society may, in fact, be rooted in a very old prejudice with regard to the Other and those who consort with linguistic others (cf. Cohn, 1976).

\section{Metaphor}

The translation of metaphor is a recurrent area of difficulty for the literary translator. Given the prevalence of metaphorical language in everyday discourse, most translators have to deal with the problem of transferring metaphor from one language to the other. However, there is a relationship between play, translation and metaphor that goes beyond the incidence of free and fixed modulation in translation practice. Metaphors, like play are paradoxical. They link two disparate semantic fields which are not normally linked. The metaphor depends for its dramatic effect on the two notions or images remaining separate while they must, at the same time, be joined together if the metaphor is to make any sense. Through its paradoxical status, metaphor, like play, allows the unlikely, or in some cases, the impossible to happen. James Carse (1987) argues that in joining like to unlike metaphor is emblematic of all language, "at its root, all language has the character of metaphor, because no matter what it intends to be about it remains language and remains absolutely unlike whatever it is about" (p. 87). If Carse is expressing here the similarities between the arbitrary nature of signifiers in language and the operations of metaphor, it is interesting to note the attention drawn to the presence/absence feature of language. Metaphor draws our attention to what is not there, to unlikely or surprising associations, which most of the time are absent in the reader's and indeed, presumably, in the writer's mind. Much as play activities are found acceptable because they are framed as play, metaphorical statements would be deemed nonsensical if they were interpreted literally, if one did not apply metaphorical interpretive procedures. Lewis Carroll in Alice in Wonderland exploits this feature of language by demonstrating the absurd consequences of literal interpretations of metaphor.

The connection between play, metaphor and translation becomes apparent when we consider Arthur Koestler's distinction between association and bisociation. He puts forward the thesis that 
"associative routine means thinking according to a given set of rules on a single plane, as it were. The bisociative act means combining two different sets of rules, to live on several planes at once" (p. 644). Bisociative thinking, by combining two previously unrelated areas in a new synthesis, both typifies the way original insights emerge and demonstrates the metaphorical nature of inventive thought. By virtue of its paradoxical nature and its role in preparing humans to create possible frames for unlikely situations, play parallels and prepares the way for metaphor and discovery. In the literary text, part of the enjoyment must come from the sense of revelation that comes from the association of the like and the unlike in metaphor, pointing to cognitive possibilities of play in fiction. Like metaphor, translation joins together like and unlike, two disparate languages. The languages are joined, this is why the translation makes sense, but they are at the same time separate, there could be no translation without a distinct original. Furthermore, the bisociative quality of metaphor is present also in the translator's constant movement between different languages and cultures. The translator must, by definition, operate on two or more planes at any given time. The tangible expression for translators of this perpetual commerce is what Koestler calls the "A-ha!" experience. This occurs when the translator is translating a text and comes across a word or often an expression for which there is no immediately obvious translation. Minutes, hours, days can be spent searching for an appropriate equivalent and then, all of a sudden, the appropriate equivalent is found and there is the release of discovery. It is arguably this bisociative process that is being alluded to in the evocation of the creative "energy" of translation in Romantic and Hermeneutic theories of translation and notions of intuition (Pope, Arnold) or translatorial relativity (Neubert) that are recurrent themes in thought on translation practice. When the organisers of the XIIth FIT Congress in Belgrade in 1990 opted for the theme, "Translation, a creative profession," they had wittingly or unwittingly, drawn attention to the profoundly bisociative nature of the translation process. Hence, translation as practice and not only as product, can be shown to perform an intellectually formative role in education, its metaphorical, ludic dimensions grounding creating and discovery. 


\section{Paradox}

In describing the operations of play and metaphor as paradoxical, it is worth considering in greater detail the question of translation and paradox. Nicholas Falletta in his work The Paradoxicon (1985) concludes that, historically, there are three high points of interest in paradoxical thinking: Ancient Greece, the Renaissance and the Modern Era (p. xix). Peter Hutchinson (1983), surveying the Western literary tradition, expands on Falletta's observation:

Historical periods of intense intellectual activity and self-discovery seem to have provided the best moments for paradox to flourish. As a self-conscious, overtly intellectual, often ingenious exercise of mental faculties, it requires a responsive audience as much as a brilliant exponent (p. 87).

Anton Rapoport, the games theorist and communications expert, sees a firm link between reflection on paradox and the emergence of many major ideas in mathematics and science.Zeno's paradox of Achilles and the tortoise gave rise to the idea of convergent infinite series; antinomies led to Gödel's famous theorem; and the paradoxical result of the Michelson-Morley experiment on the speed of light was the backdrop to Einstein's work on the theory of relativity. Rapoport declares that "paradoxes have played a dramatic part in intellectual history, often foreshadowing revolutionary developments in science, mathematics and logic" (cited in Falletta, p. xviii). One effect of play and paradox is that they lead to reflection on the way that sense and reality are organised. Koestler suggests that comic discovery is paradox stated and scientific discovery, paradox resolved (Koestler, p. 646). Fiction often serves to highlight paradoxes of language, sense, meaning, for purely comic purposes but also to ensure the continuing possibility of literary experiment in fiction, witness the work of Laurence Sterne in English. It is because paradoxes force readers and writers to reflect on framing procedures in fiction, that it is possible for innovation and evaluation to occur. Evaluation may result because the reader is forced to become aware of the invented nature of fiction, this distance permitting the critical approach that is denied to the unproblematic consumer of texts. Innovation takes place where paradox makes one aware of assumptions, premises, the taken for granted, the rules that govern the organisation of the sense. This is the necessary prerequisite 
for the profound or radical redrafting of rules which constitute aesthetic change.

A translation is paradoxical because it both is and is not the original. It only exists because of the original but the aim of communicative translations as defined by Newmark is that it should read like an original. The original is simultaneously absent and present. The translator, of course, is more likely to be more aware of the paradoxical status of the translated text though it is likely that the paradoxical sensitivity on the part of the translation user/receiver is a function of the form of translation, i.e. the viewer of a sub-titled television programme is made more immediately aware of the presence/ absence paradox of translation than the end-user of a software localisation product. Linking translation and paradox has two consequences. Firstly, the cognitive role of translation is once more emphasised as part of the more general catalytic presence of paradox in human thought and culture. Secondly, the role of translation in the emergence of new literatures is arguably bound up with the radical redrafting of rules that is one possible consequence of thinking through paradox. That is to say, translating from French into German, makes one aware of all the assumptions, those things that are taken for granted when you are a daily user of the language so that the questioning implicit in the act of translation can become the basis for transformation of literary practice. To paraphrase Koestler, translation is paradox stated and aesthetic renewal, paradox resolved.

\section{Readers}

Over the last two decades much attention has been paid in the area of literary criticism to the reader. The reader as a function of the intersubjective nature of language, authorial anticipation of interpretive moves by the reader as a factor in generating new textual strategies, the vital role of the reader in the linguistic economy of texts, the reader as woman, all these observations have lead to an extensive reevaluation of the processes of interpretation ${ }^{1}$. The implications of reader research for translation theory are many. One area of potential interest is highlighted

1. For a useful summary of the different schools of thought on reading see Jonathan Culler (1983), pp. 31-83. 
by Elizabeth Bruss's tripartite division of the games authors play with their readers into zero-sum, mixed motive and cooperative games. The games are graded on the degree of authorial cooperation, zero-sum where cooperation is minimal and co-operative where cooperation is total (Bruss, 1977). These distinctions are worth bearing in mind for two reasons, the first is to do with translator job satisfaction and the second is translator training.

Let us consider what happens in the case of the text that cooperates fully with the reader. The wholly transparent text is, in fact, as lacking in playfulness as the zero-sum text. Just a power presupposes resistance, the text must resist at some level the reader's attempts to understand it if any pleasure, cognitive or affective, is to be derived from it. In this respect, reading is rather like the game of hide-and-seek described by Berne (1985). Arguing that the culmination of each game is the payoff, Berne states that the preliminary moves set up this situation for payoff but "they are always designed to harvest the maximum possible satisfaction at each step as a secondary product" (p. 55). In a game of hide-and-seek a child will be disappointed if found too soon by its parent but so also will the child, if it is not found at all. The aim of a successful game is to make the search last as long as possible - the pleasure of suspense - but to be found in the end. As Berne points out, "among older children, one who finds an insoluble hiding place is regarded as not being a good sport, since he has spoiled the game" (p. 117) The writer's strategy, to be successful entails resistance through parallel, counterpoint, narrative devices, defamiliarisation techniques and so on but if there are too many insoluble hiding places the reader is likely to want to play elsewhere. Hence, many texts tend to maintain an equilibrium between competitive and cooperative elements.

The consequences for professional translators are clear if rarely articulated. Texts that offer no resistance, though welcome at first, soon become tedious. Excessive specialisation can mean greater efficiency and accuracy but may also entail intense boredom. Translators should ideally not work for overly long periods on just the one kind of text as the real gains in interpretive cooperation may be more than offset by the genuine loss of interest. In effect, many translators, particularly those working freelance, are not faced with the repetitive joylessness of 
cooperative games. Texts are generally sufficiently varied to keep the element of resistance in play. As regards translator training, students are not helped by an unvarying diet of pragmatic texts offering varying degrees of resistance. The highly competitive nature of the interpretive game presented by many literary texts ensures that the student translator does experience the more agonistic end of translation practice and interest is likely to be sustained as result (once there are not too many zero-sum games, in which case the student translator may stop playing altogether). In the design of any undergraduate or graduate course in translation practice, there must therefore be a careful balance of the three ludic text types.

\section{Limits}

Louis-Jean Calvet in Les jeux de la société (1978) claims that "nous ne jouons en fait que dans notre héritage culturel et social, nous sommes les joueurs d'un lieu et d'un temps" (p. 208), citing the example of the American who plays a game of Go with the narrator in Kawabata's novel The Master of Go. The narrator is unimpressed with his opponent's playing and blames this on the fact that the latter is American and not Japanese. Readers, too, play in a particular time and place and, as Marxist critics have argued over the years, this influences the nature of their interpretations. However, if a reader's and by extension a translator's intertextual competence is in part historically and ideologically determined, $s /$ he is not an interpretive prisoner of circumstance, denied the play of possibility. Hans Robert Jauss (1978) sees the experience of reading as potentially freeing the reader from social overdeterminedness:

L'expérience de la lecture peut le [le lecteur] libérer de l'adaptation sociale, des préjugés et des contraintes de sa vie réelle, en le contraignant à renouveler sa perception des choses. L'horizon d'attente propre à la littérature se distingue de celui de la praxis historique de la vie en ce que non seulement il conserve la trace des expériences faites, mais encore il anticipe des possibilités non encore réalisées (p. 75).

The speculative, anticipatory freedom of play and reading allows the readers to construct or imaginatively experience other, different worlds which may challenge assumptions, practices, outlooks in the everyday 
lifeworld of the empirical reader. The ability to project oneself into possible worlds, the sense of foresight which Jacob Bronowski saw as humanity's defining characteristic, is evidence of the shortcomings of an ideological determinism that would see readers as the hapless victims of their politics and time. Translators are, of course, readers and translations are written to be read. Translators, as we saw earlier, are heavily dependent on the processes of projection and identification irrespective of the nature of the text (literary or non-literary). This margin of speculative play - greater or lesser depending on the nature of the text, the translator's linguistic and cultural competence and so on - guarantees the idiosyncratic trace of the translator, the impossibility of reducing him/her to an ideological cypher.

Jifí Levý (1967) in his description of translation as a decision process is guided by the insights of mathematical game theory. He is interested in the process of translation as a game with rules and strategies. Translation involves, "a series of a certain number of consecutive situations - moves as in a game - situations imposing on the translator the necessity of choosing among a certain (and very often exactly defineable) number of alternatives" (p. 1171). Levý fails to recognise that unlike the rational players of Von Neumann's and Morgenstern's theory who have access to total information, translators do not always have access to total information on SL texts (intentional fallacy) and TL reception and the reasons for translation choices can be dictated by factors that are irrational as well as rational. Levý does acknowledge, however, the provisional pragmatism of the translator:

Translation theory tends to be normative, to instruct translators on the OPTIMAL solution; actual translation work, however, is pragmatic; the translator [...] resolves for one of the possible solutions which promises a maximum of effect with a minimum of effort. That is to say, he intuitively resolves for the so-called MINIMAX STRATEGY [J. L.'s emphasis] (p. 1179).

However, creativity in translation is not simply a function of ludic indeterminacy or a resistance to closure. Limits generate its unlimitedness. Edwin Gentzler (1993) notes the importance of translation for a generation of American poets in the 1960s and claims: 
The very limits and constraints of the activity of translating seem to help in making possible new verbal constructions, and thus the attraction of translation as a mode in itself for this generation of American poets (p. 42).

The conviction shared by Raymond Queneau, Georges Perec, Italo Calvino and others that constraints are creative finds parallels not only in the history of versification in world culture but also in the practice of translation through the ages ${ }^{2}$. Here the notion of play is related to free movement within limits, as in the parts of a machine, le jeu des pistons. Translation as performance, transformance (Godard), the suggestive ambiguity of interprète in French are further areas of exploration in ludic approaches to translation. A satisfactory ludic theory of translation could make a decisive contribution to translation studies and even more importantly, re-centre translation as an essential discipline of the human mind.

Michael Cronin, School of Applied Languages, Dublin City University, Dublin 9, Ireland.

\section{References}

BATESON, Gregory (1978). "A Theory of Play and Fantasy," Steps to an Ecology of Mind. London, Paladin, pp. 150-166.

BERNE, Eric (1985). Games People Play. Harmondsworth, Penguin.

BRUNER, Jerome S., Alison Jolly and Kathy Sylva, eds. (1976). Play: Its role in Development and Evolution. Harmondsworth, Penguin.

2. Perec, Queneau and Calvino were all members of the avant-garde Oulipo literary group. In a presentation of the group's work at the Chartreuse de Villeneuve-lès-Avignon, the members declared: "L'Oulipo, qui compte en son sein des écrivains, des scientifiques, se propose de réintroduire dans l'écriture littéraire contemporaine la notion de contrainte qui en avait été un peu chassée par l'idéologie post-romantique du spontanéisme, de l'aléatoire et du génie inné, tumultueux" (Oulipo, 1981, p. 431). 
BRUSS, Elizabeth (1977). "The Game of Literature and some Literary Games," New Literary History, IX(1), Autumn.

CAILLOIS, Roger (1967). Les jeux et les hommes. Paris, Gallimard.

CALVET, Louis-Jean (1978). Les jeux de la société. Paris, Payot.

CARSE, James (1987). Finite and Infinite Games. Harmondsworth, Penguin.

COHN, Norman (1976). Europe's Inner Demons. London, Paladin.

CULLER, Jonathan (1983). On Deconstruction: Theory and Criticism after Structuralism. London, RKP.

FALLETTA, Nicholas(1985). The Paradoxicon. Northamps, Turnstone.

GENTZLER, Edwin (1993). Contemporary Translation Theories. London, Routledge.

HUIZINGA, Johan (1949). Homo Ludens: A Study of the Play Element in Culture. London, Paladin.

HUTCHINSON, Peter (1983). Games Authors Play. London, Methuen.

JAUSS, Hans Robert (1978). Pour une esthétique de la réception. Paris, Seuil.

JONG, Nelleke de, and van den Berg (1993). "Narrator and Time Translator and Time, the Methodological Leitmotiv," International Translation Studies Conference, Vienna (September).

KOESTLER, Arthur (1976). "Association and Bisociation," in Bruner, Jolly and Sylva, eds. (1976).

KOSTER, Cees (1993). "(Re-)Considering (the Status of Interpretation in) DTS," International Translation Studies Conference, Vienna (September). 
LEVÝ, Jiří (1967). "Translation as a Decision Process," To Honour Roman Jakobson: Essays on the Occasion of his Seventieth Birthday, vol. II, The Hague, Mouton.

OULIPO (1981). Atlas de littérature potentielle. Paris, Gallimard.

PICARD, Michel (1986). La lecture comme jeu. Paris, Minuit.

REYNOLDS, Peter C. (1976). "Play, Language and Human Evolution," in Bruner, Jolly and Sylva, eds. (1976).

STEWART, Susan (1978). Nonsense: Aspects of Intertextuality in Folklore and Literature. Baltimore, John Hopkins University Press.

VYGOTSKY, Lev S. (1976). "Play and its Role in the Mental Development of the Child," in Bruner, Jolly and Sylva, eds. (1976).

\begin{abstract}
Keeping one's distance: Translation and the play of possibility - This article proposes a ludic theorisation of translation examining the implications of the concept of play for translation theory and translation pedagogy. The equation of play with a simulative mode of action points to the centrality of mechanisms of identification and projection in the translation interpreting classroom. The shift from the pre-operational to the operational level of logic and the metacommunicative and metalinguistic dimensions to play and translation demonstrate the cognitive importance of the latter. in intellectual development and the elaboration of identity. Play, metaphor and translation are linked through the concept of bisociative thinking which grounds the essential creativity of translation and its capacity for discovery. The paradoxical nature of translation and play are considered both in relation to the cognitive possibilities of translation and its contribution to aesthetic renewal. The use of a tripartite division of ludic text types in translator education and the potential of limits are further evidence for the significance of the ludic dimension to translation.
\end{abstract}


RÉSUMÉ: En gardant ses distances: la traduction et le jeu du possible - Cet article propose une théorisation ludique de la traduction examinant les implications du concept de jeu pour la théorie et la pédagogie de la traduction. L'équation du jeu avec un mode simulatif d'action fait ressortir le caractère central des mécanismes d'identification et de projection dans la classe de traductioninterprétation. Le passage du niveau pré-opérationnel au niveau opérationnel de logique et le passage des dimensions métacommunicative et métalinguistique au jeu et à la traduction démontrent l'importance cognitive de ces activités dans le développement intellectuel et la constitution de l'identité. Le jeu, la métaphore et la traduction sont liés dans le concept de la pensée bisociative qui fonde la créativité essentielle de la traduction et sa capacité de découverte. La nature paradoxale de la traduction et du jeu est envisagée tant en relation avec les possibilités cognitives de la traduction que sous l'angle de sa contribution à un renouvellement esthétique. L'utilisation d'une division tripartite de types ludiques de textes dans la formation des traducteurs et le potentiel créatif des limites sont une preuve de plus en faveur de l'importance de la dimension ludique de la traduction. 